ROCZNIKI PEDAGOGICZNE

Tom 13(49), numer $2-2021$

DOI: https://doi.org/10.18290/rped21132.3

\title{
GODNOŚĆ CZŁOWIEKA ŹRÓDŁEM CELÓW WYCHOWANIA I ZADAŃ SZKOŁY
}

Celem przedstawionego opracowania jest ukazanie istoty i funkcji godności człowieka w procesie wychowania, ze szczególnym zwróceniem uwagi na jej funkcję integrującą przymioty osoby: rozumność - mądrość, wolność, odpowiedzialność.

Przedmiotem analiz będzie głównie godność osobowa i osobowościowa oraz wynikające $\mathrm{z}$ tych dwóch kategorii godności cele i zadania w praktyce wychowania szkolnego.

\section{DEFINICYJNE UJĘCIE POJĘCIA GODNOŚCI}

Kategoria godności występuje w języku potocznym i naukowym. W codziennym życiu spotykamy wyrażenia o charakterze opisowym, wartościującym, normatywnym, w którym występuje słowo „godność”. Często spotykamy się z określeniami: „godnie się zachował”, „niegodnie się zachował”, „szanuje swoją godność”/,szanuj swoją godność”, „to jest poniżej mojej godności”, „,co dzieje się z twoją godnością”, „moja godność mi na to nie pozwala”, ,jak pana godność”, „godność nauczyciela” itp.

W jaki sposób definiowana jest godność w ujęciach słownikowych i encyklopedycznych?

Najkrótszą definicję godności spotykamy w Słowniku katolickiej nauki społecznej: „godność człowieka, specyficzna wartość osoby ludzkiej” (Podrez, 1993, s. 54-55). W Leksykonie PWN podkreślony jest indywidualny

Prof. dr hab. KRYSTYNA ChA£AS - Katedra Dydaktyki, Edukacji Szkolnej i Pedeutologii, Instytut Pedagogiki, Wydział Nauk Społecznych, Katolicki Uniwersytet Lubelski Jana Pawła II; adres do korespondencji: Al. Racławickie 14, 20-950 Lublin; e-mail: krystyna.chalas@kul.pl; ORCID: https://orcid.org/0000-0002-8303-5211. 
i społeczny oraz aksjologiczny wymiar godności, określanej jako „pozytywna wartość człowieka, która winna przysługiwać mu w kontakcie $\mathrm{z}$ innymi ludźmi" (Kaczorowski, 2004, s. 388).

W Encyklopedii popularnej znajdujemy następującą próbę zdefiniowania tego pojęcia: „godność - uniwersalna i niestopniowalna, zasługująca na szacunek własny i innych ludzi wartość człowieczeństwa przysługująca każdemu człowiekowi bez wyjątku, także cnota jako złoty środek między wadami zarozumialstwa i służalczości (Arystoteles)" (2010, s. 335).

$\mathrm{Z}$ pedagogicznego punktu widzenia na uwagę zasługuje definicja godności znajdująca się w Encyklopedii katolickiej, bowiem ma ona charakter holistyczny i podkreśla wartość osoby, funkcjonowanie relacyjne człowieka, wskazuje na wymiar normatywny. Według tego źródła

[...] godność (z łac. dignitas), szczególna wartość człowieka jako osoby pozostającej w relacjach interpersonalnych (ostatecznie do osoby Boga), uzasadniających i usensowniających życie osobowe, a także pozytywnie wartościująca relacje do własnej osoby i grupy (np. zawodowej, klasowej, narodowej), z którymi się jednostka identyfikuje. Konstytuującym komponentem ustosunkowania się jest samoocena polegająca na przeżywaniu swojej wartości i pozytywnego obrazu, która motywuje do moralnie wartościowych zachowań, uodparniania się na wszelakie formy manipulacji i zniewalania oraz wpływa na radzenie sobie w sytuacjach trudnych. Godność zakłada poczucie wewnętrznej wolności, autodeterminacji (podmiotowości) i odpowiedzialności (Chlewiński, Zaleski, 1989, kol. 1231-1232).

Należy przy tym podkreślić, że powyżej wskazane ujęcie godności nawiązuje do wielu celów wychowania, zwłaszcza do poszanowania własnej wartości i wartości drugiego człowieka, budowania pozytywnego obrazu siebie i przestrzeni własnej wolności, kształtowania podmiotowości, kształtowania postawy odpowiedzialności, rozwijania umiejętności rozwiązywania problemów, tworzenia pozytywnych relacji interpersonalnych. Godność jest więc źródłem konkretnych celów wychowawczych.

Analiza literatury wskazuje na różne ujęcia godności:

- filozoficzne (antropologiczno-metafizyczne),

- teologiczne,

- psychologiczne,

- socjologiczne,

- etyczne,

- prawne,

- pedagogiczne. 
W ujęciu filozoficznym (antropologiczno-metafizycznym) u podstaw godności znajduje się rozum człowieka i jego wartość, stanowiąca cel sam w sobie. Godność osobowa jest przymiotem osoby ludzkiej, najważniejszą, obiektywną wartością ontyczną.

Godność w ujęciu teologicznym jest ujmowana w wymiarze nadprzyrodzonym oraz rozpatrywana $\mathrm{w}$ świetle aktu stworzenia, odkupienia i objawienia. Człowiek został stworzony na obraz i podobieństwo Boże. Ten obraz Boga w człowieku stanowi o szczególnej wartości człowieka, szczególnej jego godności, jako dziecka Bożego. Godność człowieka odsłania transcendencję człowieka, jego uczestnictwo w życiu osób Bożych (Stępień, 2016, s. 377-378).

W ujęciu psychologicznym godność stanowi składnik osobowości. Źródłem i czynnikiem rozwoju jest aktywność człowieka. Józef Kozielecki wyróżnia trzy źródła godności:

- wierność wobec siebie,

- podejmowanie celów pozaosobistych,

- działalność twórcza (Kozielecki, 1977, s. 17-18).

Opisując je w aspekcie pedagogicznym, jest to:

- trwanie przy właściwych wartościach i urzeczywistnianie własnej, ale właściwej hierarchii wartości;

- służba drugiemu człowiekowi, grupom, wspólnotom, społeczeństwu, narodowi;

- podejmowanie aktywności twórczej.

W ujęciu socjologicznym godność ujmowana jest przez pryzmat ról społecznych, zawodowych, pozycji społecznej. Określana jest jako godność osobista. Katarzyna Stępień wskazuje, że wyznacza ona pewien status życia i przypisywane mu zaszczyty, honory oraz miejsce w hierarchii społecznej, zawodowej. Odpowiada jej określony sposób zachowania ze względu na pozycję jednostki lub pełnioną przez nią rolę. Terminy „godny”, „godność” używane na określenie tych zachowań dotyczą zarówno powagi, piastowania zaszczytnego stanowiska, jak i towarzyszących mu przekonań o potrzebie respektu, szacunku, o zasługiwaniu na przywileje (Stępień, 2016, s. 379).

W aspekcie etycznym podstawę godności stanowi możliwość i zdolność świadomego, wolnego, odpowiedzialnego działania. Godność wyraża więc zdolność człowieka do działań etyczno-moralnych. Jest wartością normatywną, zobowiązującą do życia i postępowania na miarę swej wartości, pełni człowieczeństwa i powołania człowieka. 
Pedagogiczne ujęcie wolności ze względu na nadrzędny cel wychowania, którym jest integralny rozwój osoby ucznia, w sposób naturalny integruje powyższe ujęcia: wymiar naturalny i nadprzyrodzony. Karol Wojtyła podkreśla, że o wielkiej godności człowieka świadczy jego nadrzędna pozycja w stosunku do całej przyrody oraz antropologia. Człowiek jako przedstawiciel ludzkości sprowadza i potwierdza swą wyższość w doświadczaniu historii, kultury, techniki, twórczości, produkcji. Indywidualne skutki działania człowieka, zbiorowości społecznych bądź ogólnie wszystkich ludzi świadczą o nim, o jego wyższości nad światem widzialnym (Wojtyła, 1994, s. 418).

Podstawą godności jest istota człowieka, czyli to, kim jest sam w sobie, decyduje o niej rozumność - mądrość, odpowiedzialność, zdolność do miłości, twórczości, transcendencji, jego życie wewnętrzne. Godność zawiera prawdę o człowieku, jego człowieczeństwie: człowiek jest osobą, wielką wartością od swego poczęcia aż do naturalnej śmierci; jest zawsze celem, nigdy środkiem do celu.

Mimo wielowymiarowego ujęcia, godność łatwiej postrzegać i doznać, niż ją określić i o niej mówić, badać, projektować związane z nią działania pedagogiczne i je realizować, by urzeczywistniać tę wartość w wymiarze indywidualnym i społecznym.

Janusz Mariański - wybitny polski socjolog, zainteresowany problemami pedagogicznymi - wskazuje, że godność ogniskuje takie pojęcia, jak: „człowieczeństwo, dostojeństwo, dobre słowa, dobre imię, cześć, honor, duma, powaga, uznanie moralne, poważanie, szacunek dla siebie i innych, szlachetność, miłość bliźniego, poczucie braterstwa, zaszczyt, humanizm, podmiotowość, autonomia, zacność, przyzwoitość, czcigodność, dzielność moralna, ambicja, przeżywanie własnej wartości, odwaga, ważność jednostki, wartość człowieczeństwa, poczucie własnej wartości, godność sumienia, postawy godne, przywrócenie komuś czci" (Mariański, 2016, s. 13). Wszystkie wymienione elementy są z pedagogicznego punktu widzenia ważne, stanowią bowiem cele i pożądane osiągnięcia wychowawcze w aspekcie urzeczywistniania tej wielkiej wartości, jaką jest godność.

\section{GODNOŚĆ OSOBOWA I GODNOŚĆ OSOBOWOŚCIOWA}

Godność osobowa - godność osoby ludzkiej jest określana jako wartość wartości osoby.

W Encyklopedii aksjologii pedagogicznej godność osobowa została zdefiniowana jako „właściwość człowieka wypływająca z jego specyficznej struk- 
tury bytowej, ujawniająca się w aktach rozumnego i wolnego działania; bytu osobowego, wskazująca na jego szczególną wartość ontyczną i związaną z tym nieredukowalność do roli środka" (Stępień, 2016, s. 376).

Źródłem godności jest wartość osoby rozumianej jako byt duchowo-cielesny, którego cechą jest zdolność rozumnego i wolnego samostanowienia, bezinteresownej miłości, transcendencji. Godność osobowa jest stała, nieredukowalna, niezbywalna i równocześnie zobowiązująca.

Według A. Szostka ,[...] godność osobowa jako wartość ontyczna określonego bytu nie ma autentycznego wobec siebie bieguna (jako że nie ma antybytu) [...]. Natura człowieka odróżnia go od innych bytów nie tylko w sensie czysto opisowym, ale i aksjologicznym. Z racji tego, kim jest człowiek, jest cenniejszy niż inne byty na ziemi. Cenność tę z faktu bycia osobą - określa się mianem godności osobowej” (Szostek, 1989, s. 46).

Godność osoby jest wartością daną, uniwersalną. Przysługuje wszystkim ludziom bez względu na wiek, płeć, pochodzenie, wykształcenie, wykonywany zawód, narodowość, sytuację społeczno-narodową czy polityczną, przynależność religijną, wyznawane i realizowane wartości. Jest wartością daną, ale też zadaną. Uznaje się ją za źródło powinności moralnych i zobowiązań rozwojowych, samodoskonalących się w aspekcie indywidualnym i społecznym.

Z powyżej wskazanej charakterystyki wynika, że odgrywa doniosłą rolę w procesie wychowawczo-dydaktycznym. Jak podkreśla J. Mariański, „z niej wynikają postulaty moralnego doskonalenia się oraz powinności afirmowania innych osób w imię ich godności” (Mariański, 2017, s. 16).

Należy podkreślić, że godność osobowa jest wartością zadaną. Jak podkreśla A. Szostek, jest tą „wartością, która wywołuje i uzasadnia w podmiocie specyficzną, moralną powinność określonego działania" (Szostek, 1989, s. 109).

$\mathrm{Na}$ ten fakt w aspekcie pedagogicznym zwraca uwagę A. Lekka-Kowalik. Autorka podkreśla, że:

Z godnością w sensie ontologicznym płynie też godność ludzkiego działania jako ucznia, nauczyciela, rodzica. Ponieważ tak rozumiana godność przysługuje osobie jako osobie, domaga się od każdej osoby - tak względem siebie i swej własnej godności, jak i godności innych osób - adekwatnej odpowiedzi. Adekwatną odpowiedzią na godność człowieka jest miłość wyrażająca się w aktach afirmacji, a osoba (jej godność i wyposażenie) staje się ostatecznym kryterium moralnej słuszności działań (Lekka-Kowalik, 2016, s. 384). 
Godność nabiera wymiaru treściowego w doświadczeniu moralnym, w kontaktach intarpersonalnych i interpersonalnych, których wyrazem jest m.in. poszanowanie własnej osoby $i$ innych ze względu na ich wartość.

Godność osobowa jest podstawą i warunkiem nabywania w drodze działań podmiotu godności osobowościowej. Godność osobowościowa jest określana jako „doskonałość, jaka zarodziła się w działaniu moralnie wartościowym i utrwaliła w czyjejś osobowości” (Mazurek, 2001, s. 19).

Czynnikami warunkującymi godność osobowościową są: akt decyzji, intelekt, wola. Te trzy elementy są ze sobą zintegrowane, wzajemnie się przenikają i warunkują. Należy też zauważyć, że godność osobowościowa jest uwarunkowana orientacją aksjologiczną wyrażaną w urzeczywistnianiu własnej i właściwej hierarchii wartości, prowadzącej do integralnego rozwoju, pełni człowieczeństwa. Stanowi to aksjologiczną podstawę jej rozwoju. Godność osobowościowa zależy od człowieka, jego postaw, zachowań, działań ukierunkowanych, skoncentrowanych na dobru, dobru obiektywnym. Wartość ta może być przez człowieka w różnym stopniu budowana, ale też pomniejszana, a nawet utracona. Do jej degradacji prowadzą własne zachowania człowieka i niemoralne, aspołeczne jego postawy, a więc czynniki wewnętrzne. Źródłem jej budowania lub pomniejszania aż do utraty jest zatem sam podmiot działania, który kształtuje ją poprzez jakość swojego życia, wyrażająca się w stopniu urzeczywistniania wartości uniwersalnych, moralnych, duchowych. Im ten stopień jest wyższy, tym wyższy poziom godności osobowościowej.

Czynnikami zewnętrznymi warunkującymi poziom godności osobowościowej są: drugi człowiek - wzór osobowy „pociągający w górę”; środowisko społeczno-kulturowe, które „woła” o wyższą kulturę życia i funkcjonowania w społeczności, stwarzając jednocześnie ku temu warunki; różnego rodzaju grupy i wspólnoty, które w swych celach i programach sytuują integralny rozwój i pełnię człowieczeństwa. Należy przy tym zaznaczyć, że wśród czynników zewnętrznych występują „totalitarne systemy polityczne, uwłaczające człowiekowi warunki pracy, zmasowana indoktrynacja" (Mazurek, 2001, s. 55), które prowadzą do blokad rozwojowych, poniżania godności osobowej, rzecz w tym, by tej mocy człowiek się nie poddał w swojej życiowej wędrówce do osiągnięcia pełni człowieczeństwa.

$\mathrm{Z}$ tego, co zostało wyżej powiedziane, przed szkołą wyrastają dwa podstawowe zadania.

W centrum działalności wychowawczo-dydaktycznej stoi osoba, ze swą nienaruszalną godnością daną i zadaną. Stąd przed szkołą stoi podstawowe 
zadanie: stworzyć warunki do wzmacniania poczucia godności, swej wartości oraz rozwijania godności osobowościowej. Istotnego znaczenia nabiera strategia świadectwa, uczenie się od wzorów osobowych godnych naśladowania, które staną się stymulatorami rozwoju.

Wzmacnianie poczucia godności staje się ważnym zadaniem wychowawczym, bowiem - jak podkreśla A. Lekka-Kowalik - „Poczucie godności pomaga stawać czoło trudnym czy niebezpiecznym okolicznościom, wytrwać w przekonaniach, uchronić się przed nieszanowaniem osób stojących niżej w hierarchii społecznej (np. majątkowej, politycznej, zawodowej), służalczością wobec stojących wyżej, a więc kształtować postawy ludzi (cnoty) i relacje interpersonalne, które sprzyjają respektowaniu godności ontycznej. Poczucie godności jest gwarantem jej poszanowania" (Lekka-Kowalik, 2016, s. 386).

Drugim ważnym zadaniem jest stwarzanie warunków i szans rozwijania godności osobowościowej. Płaszczyznę realizacji tego zadania stanowi wychowanie ukierunkowane na wartości moralne. W literaturze występują różne ich podziały i zakresy.

Mieczysław Łabocki wskazuje na wartości moralne w kontekście wychowania moralnego. Są nimi: altruizm (miłość), wolność, tolerancja, wartość osoby ludzkiej, poczucie odpowiedzialności, nieszkodzenie, prawda (Łabocki, 2002, s. 97).

Zestaw wartości moralnych wyróżnianych przez R. Jedlińskiego przedstawia się następująco: dobro innego człowieka, wierność, bohaterstwo, uczciwość, godność, szczerość, honor, sprawiedliwość, miłość, odpowiedzialność, przyjaźń, pokora, skromność (Jedliński, 2000, s. 25).

Na uwagę zasługuje wyszczególnienie wartości przez D. von Hildebranda. Urzeczywistnianie wartości moralnych stanowi według tego autora trajektorię rozwijania godności osobowościowej. Autor zalicza do tych wartości: odpowiedzialność, prawość, wierność, prawdę oraz dobroć (von Hildebrand, 1982, s. 14-15).

\section{GODNOŚĆ OSOBOWA I OSOBOWOŚCIOWA MOCĄ SPRAWCZĄ URZECZYWISTNIANIA ROZUMNOŚCI, MĄDROŚCI, WOLNOŚCI, ODPOWIEDZIALNOŚCI}

Godność osobowa stanowi źródło prawdy o osobie i o sobie. Mówi ona, kim jest człowiek, jakim może i powinien się stać. Sięga przez to do antropologii chrześcijańskiej, wynosi do Boga. 
Poprzez godność budzi się świadomość, że człowiek różni się od zwierząt. Realizuje swoje cele egzystencjalne, u podstaw których znajdują się akty rozumu i decyzji, a nie proste instynkty. Należy przy tym podkreślić za M. Kalinowskim, że „Rozumność to nie tylko intelektualna zdolność myślenia i poznawania, to także umiejętność dostrzeżenia rzeczywistości, która przekracza możliwości poznawcze i otwarcia się na to, co nadprzyrodzone" (Kalinowski, 2020, s. IV). Stąd jest czerpana siła duchowa, w której kumulują się uczucia, wola, które - ukierunkowane na rozpoznanie dobra oraz zła i zaangażowanie w wybór dobra - prowadzą do mądrości. Godność zobowiązuje do rozwijania w sobie mądrości, wyrażającej się w rozeznaniu dobra i zła, oraz wybór dobra, które ma charakter dobra obiektywnego, dobra rozwojowego w aspekcie indywidualnym i społecznym w perspektywie pełni człowieczeństwa.

Godność osobowa mocą swojej cenności stanowi wartość normatywną, zobowiązującą do życia, postępowania na miarę swojej wartości, pełni człowieczeństwa i powołania człowieka. K. Stępień podkreśla, że

[...] godność wiąże się z uznaniem, że ostateczną racją ludzkich działań jest osoba pojęta jako byt w sobie i dla siebie, jako byt cel. Godność wskazuje na szczególną wartość człowieka jako osoby będącej w relacjach międzyosobowych (do drugich osób), które uzasadniają i nadają sens całemu życiu i działaniu ludzkiemu. Najpełniejszy sens wewnętrznej celowości człowieka zawiera ostatecznie relacja do osoby Boga, Absolutnego Ty jako dobra najwyższego (Stępień, 2016, s. 378).

W powyższym kontekście należy podkreślić, że z godności osobowej wynikają postulaty moralnego doskonalenia się, wyrażającego się w poszanowaniu własnej wartości - poszanowaniu siebie, poszanowaniu wartości drugiego człowieka; podejmowaniu racjonalnych, wolnych odpowiedzialnych wyborów, decyzji, urzeczywistnianiu ich w życiu. By tak się stało, człowiek musi być wolny i stawać się wolny. Godność stanowi kryterium wolności. Nie ma wolności tam/nie może być wolności tam, gdzie występuje poniżanie godności, jej umniejszanie czy próba jej degradacji - godności własnej i drugiego człowieka.

Dzięki prawdzie o osobie człowiek staje się wolny od narzucanych stanowisk światopoglądowych, wolny od wielorakiego zła, które redukuje wartość człowieka, podejmowanych prób niszczenia wielkiej wartości człowieka od poczęcia aż po naturalną śmierć. Nie ma wolności bez prawdy o osobie i prawdy o sobie. Fałszywa wizja człowieka/prawda o człowieku prowadzi do wielu nieszczęść, do zniewolenia, redukcji człowieczeństwa w człowieku. Godność osoby zobowiązuje do odpowiedzialności za siebie, własną godność 
osobową i osobowościową, godność drugiego człowieka, za jego człowieczeństwo. Związek godności człowieka z prawdą o osobie oraz z rozumnością - mądrością, wolnością, odpowiedzialnością - przedstawia Schemat 1 .

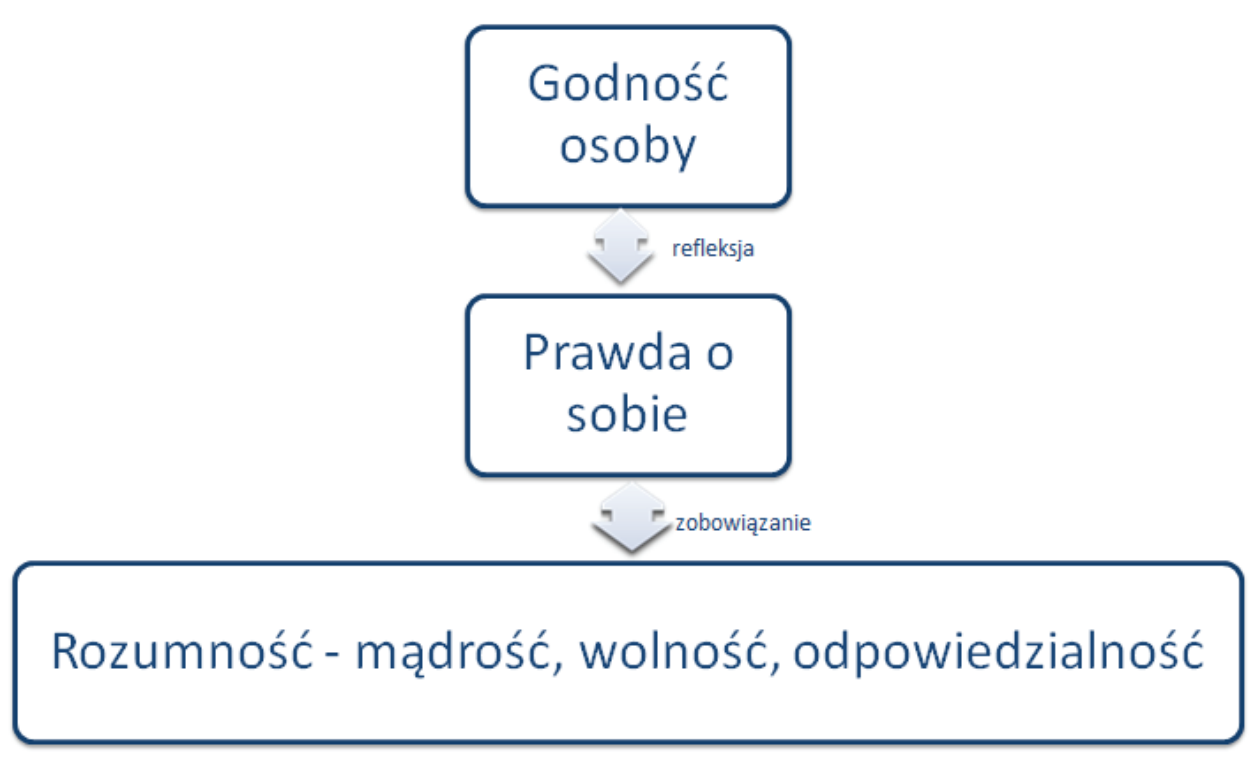

Schemat 1. Godność osoby - prawda o osobie.

W powyższym kontekście człowiek musi używać rozumu i zakotwiczać go w mądrości rozumianej jako cnota intelektualna, sprawność i wartość moralna związana $\mathrm{z}$ rozeznaniem $\mathrm{w}$ dobru i złu oraz postępowaniem według kryterium dobra obiektywnego, dobra prorozwojowego będącego podstawą budowania pełni człowieczeństwa (Nowak, 2016, s. 572).

Mądrość warunkuje wybory, warunkuje wolność wyboru, ale też wolność warunkuje mądrość. Człowiek zniewolony nie dokona mądrych wyborów. Wolność zakłada możliwość wyboru między dobrem a złem. Bóg stworzył człowieka, dając mu godność osoby, która jest obdarzana możliwością decydowania o swoich czynach i panowania nad nimi, podejmowania działań moralnie wartościowych. W nich wyraża się wolność i odpowiedzialność oraz umiłowanie prawdy; w nich wyraża się i potwierdza mądrość człowieka, jego odpowiedzialność. To one stanowią podstawę i wyraz godności osobowościowej. 
Związek między godnością osobową i osobowościową przedstawia Schemat 2.

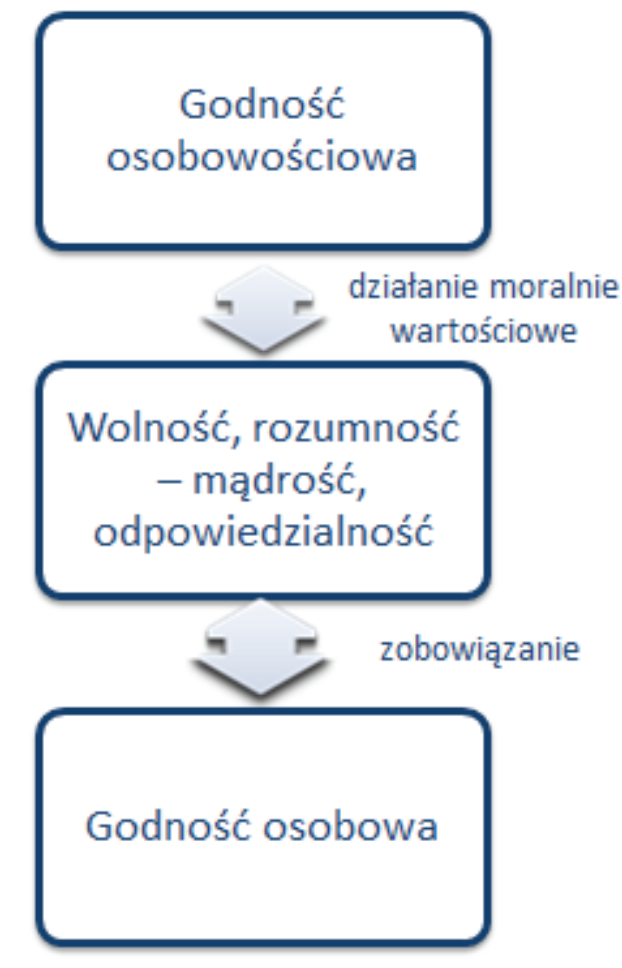

Schemat 2. Godność osobowa - działania moralnie wartościowe - godność osobowościowa.

Godność stanowi zaporę dla wszelkiego rodzaju zniewoleń i ucisków. Jest gwarantem praw człowieka, zobowiązuje bowiem do ich przestrzegania i stanowienia na miarę godności człowieka. Godność osobowa obliguje do doskonalenia siebie, do podejmowania działań moralnie wartościowych, które stanowią podstawę rozwijania godności osobowościowej. Implikuje to stawianie sobie celów bliższych i dalszych, poszukiwanie sposobów ich realizacji, strategii działania, wartościowanie siebie i uzyskiwanych efektów, a także przejawia się poczuciem swojej wartości, potrzebą urzeczywistniania własnej, ale właściwej hierarchii wartości, a co się z tym wiąże - orientacją aksjologiczną, doświadczeniem aksjologicznym, wrażliwością moralno-etyczną, prawym sumieniem. 
Związek godności (osobowej i osobowościowej) z celami i zadaniami $\mathrm{w}$ aspekcie doskonalenia siebie przedstawia Schemat 3 .

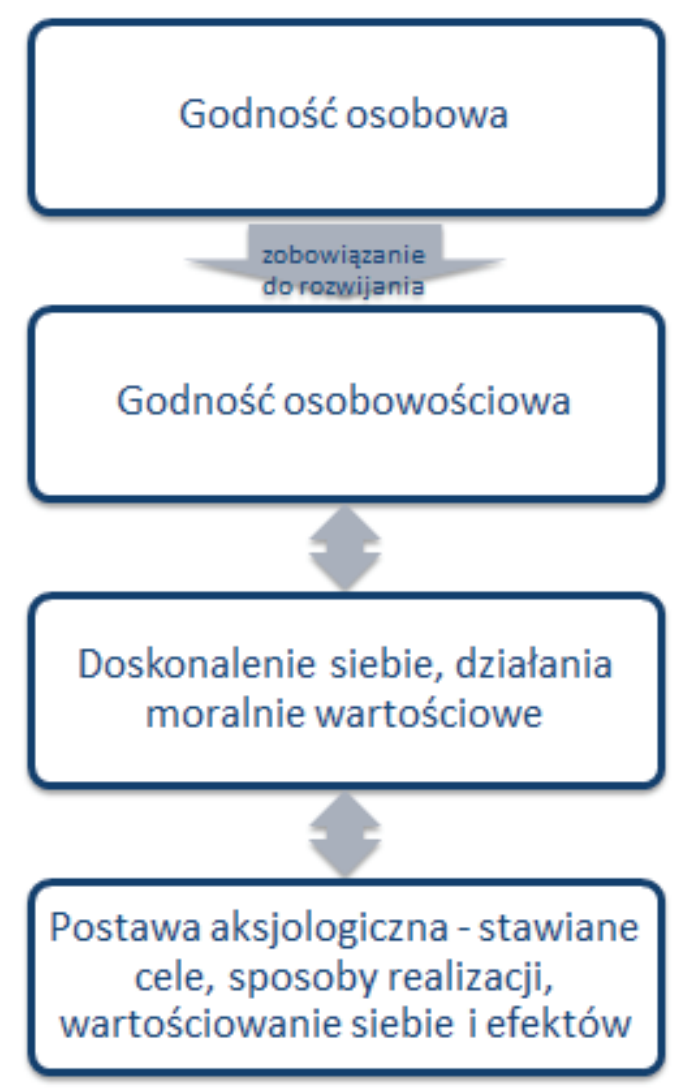

Schemat 3. Godność osobowa i osobowościowa.

Godność jako cel wychowawczy i źródło zadań dla szkoły stanowi zaporę dla relatywizmu etycznego. Miejsce godności osoby w celach wychowania jest nadrzędne. Wyznacza je jej fenomen - określa bowiem wartość człowieka, jest wartością stałą, daną, niepodważalną. Dzięki tym cechom nadaje wychowaniu mocną podstawę aksjologiczną i staje się przez to priorytetowym celem wychowania. Nic nie może stać przed wartością człowieka - osoby. Implikuje to poszanowanie godności własnej i godności drugiego człowieka. 
Jak już zostało podkreślone, godność osoby zobowiązuje do rozwijania godności osobowościowej - jako doskonałości rodzącej się w działaniach moralnie wartościowych. Wiąże się to $\mathrm{z}$ wprowadzeniem wychowanków w świat wartości, budowaniem i urzeczywistnianiem własnej, ale właściwej hierarchii wartości, prowadzącej do pełni człowieczeństwa.

Ważnym zadaniem staje się edukacja aksjologiczna i wychowanie ku wartościom.

Według K. Stępień wychowanie ukierunkowane na godność osobową polega na ,pokonywaniu i unaocznianiu wychowankowi w nim samym i w innych osobach, naprowadzaniu na wartości godności, by rozpoznawał jej obligującą do działania moc" (Stępień, 2016, s. 383).

\section{Godność osoby $\rightarrow$ poszanowanie własnej godności i godności drugiego} człowieka.

\section{Godność osobowościowa:}

- doskonalenie siebie,

- urzeczywistnianie własnej lecz właściwej hierarchii wartości,

- zaangażowanie w działania moralnie wartościowe.

\section{Edukacja aksjologiczna i wychowanie ku wartościom.}

Schemat 4. Godność - cele wychowania.

Z istoty godności osoby wypływają zadania dla szkoły. Priorytetowym zadaniem jest zapewnienie uczniom integralnego, harmonijnego rozwoju ich sfery fizycznej, psychicznej, społeczno-moralnej, kulturowej, religijnej oraz wspieranie rodziców w realizacji tego zadania. 
W powyższym kontekście można wyróżnić pięć głównych kategorii zadań, a w nich zadania szczegółowe.

1. Zadania szkoły wobec ucznia jako osoby:

- wspieranie w zdobywaniu wiedzy na temat godności osoby;

- wzmacnianie świadomości wartości ucznia jako osoby i budowanie poczucia godności;

- rozwijanie wrażliwości sumienia w kontekście wolności i odpowiedzialności;

- przygotowanie ucznia do odpowiedzialnego życia oraz odważnych i śmiałych dokonań poprzez rozwijanie swojej indywidualności;

- wspomaganie w rozpoznawaniu swoich uczuć i rozwijaniu w sobie sfery uczuciowej;

- rozwijanie umiejętności myślenia, wyrażania poglądów, samokształcenia, stylu życia, planowania swojego rozwoju i kariery zawodowej na miarę wartości osoby;

- rozwijanie umiejętności interpersonalnych, wspomaganie w budowaniu grup i wspólnot społecznych;

- stwarzanie warunków do rozwoju fizycznego, troski o zdrowie, ciało, kondycję fizyczną.

2. Zadania szkoły wobec ucznia w jego relacji do Boga:

- stwarzanie szans zdobywania wiedzy religijnej;

- pogłębianie w uczniu wiary chrześcijańskiej;

- wspomaganie w budowaniu własnego życia religijnego i dawaniu świadectwa miłości Boga;

- wspomaganie w pogłębianiu formacji religijnej;

- budzenie w uczniach poszanowania dla innych wyznań religijnych;

- wspomaganie w budowaniu wspólnot religijnych i włączanie ich doświadczeń w proces wychowawczo-dydaktyczny.

3. Zadania szkoły wobec ucznia w jego relacjach społecznych:

- budzenie świadomości, że uczeń żyje w grupach i wspólnotach społecznych;

- rozwijanie kompetencji społecznych i obywatelskich;

- kształtowanie postaw prospołecznych, w których rdzeniem jest otwartość na drugiego człowieka, zrozumienie drugiego człowieka, służba człowiekowi z miłością i ofiarnością;

- kształtowanie umiejętności rozwiązywania konfliktów społecznych;

- stwarzanie szans wielostronnego rozwoju społecznego i doświadczania jego rezultatów. 
4. Zadania szkoły wobec ucznia w jego relacji ze środowiskiem społeczno-kulturowym i przyrodniczym:

- stwarzanie szans na nabywanie umiejętności komunikowania się z samym sobą, rodziną, grupą rówieśniczą i koleżeńską, społecznością lokalną, społeczeństwem, Kościołem; ze środowiskiem kulturowym i przyrodniczym;

- stwarzanie szans na poznawanie wewnętrznych związków człowieka ze środowiskiem naturalnym i doświadczania tych związków;

- kształtowanie postawy odpowiedzialności za środowisko, w którym uczeń żyje i funkcjonuje, oraz gotowość działań prorozwojowych na rzecz środowiska.

5. Szkoła wobec ucznia poszukującego sensu życia:

- stwarzanie szans na postrzeganie swojego bytu jako osoby oraz postrzeganie sensu życia w kontekście osiągania pełni człowieczeństwa;

- stwarzanie szans na zdążanie do integralnego rozwoju, pełni człowieczeństwa;

- wspomaganie w zrozumieniu personalistycznej wartości pracy i kształtowanie postaw w tym zakresie;

- wspomaganie w zrozumieniu wartości zabawy jako formy spędzania wolnego czasu i kształtowanie odpowiedzialności w tym zakresie.

Realizacja powyższych celów i zadań będzie stanowić drogę do integralnego rozwoju. Należy przy tym podkreślić, że wymagają one jeszcze większego uszczegółowienia w zależności od poziomu rozwojowego ucznia, rozwoju kultury szkoły, potencjału społeczno-kulturowego, w którym szkoła żyje i funkcjonuje.

Godność osobowa i godność osobowościowa nadają wychowaniu charakter personalistyczny.

Godność osobowa wprowadza w wychowanie stałość i uniwersalność, wskazuje trajektorię osiągania pełni człowieczeństwa i zobowiązuje do życia na miarę wielkiej wartości człowieka.

Godność osobowościowa stanowi permanentne zadanie, które sprowadza się do urzeczywistniania wartości moralnych.

Godność osobowa i osobowościowa stanowią cel wychowania oraz są źródłem szczegółowych zadań, które powinna podjąć współczesna szkoła. 


\section{BIBLIOGRAFIA}

ChaŁas, K., Łobacz, M. (2020). Przymioty osoby ludzkiej - edukacja aksjologiczna i wychowanie ku wartościom. Lublin: Wydawnictwo KUL.

Chlewiński, Z., ZALESKi, Z. (1989). Godność. W: L. BieŃKOwSKi I IN. (red.), Encyklopedia katolicka (t. 5, kol. 1231-1232). Lublin: Towarzystwo Naukowe.

Encyklopedia popularna PWN (2010). Warszawa: Wydawnictwo Naukowe PWN.

Hildebrand von, D. (1982). Fundamentalne postawy moralne. W: D. von Hildebrand, J. A. KŁOCZOWski OP, J. PAŚciaK OP, J. Tischner (red.), Wobec wartości (s. 14-52). Poznań: Wydawnictwo $\mathrm{W}$ drodze.

JEDLIŃSKI, R. (2020). Językowy obraz świata wartości w wypowiedziach uczniów kończących szkołe podstawowa. Kraków: Wydawnictwo Naukowe Akademii Pedagogicznej 2000.

KACZOrowsKi, B. (red.) (2004). Leksykon PWN. Warszawa: Wydawnictwo Naukowe PWN.

KalinowsKi, M. (2020). Formowanie wewnętrzne człowieka o dojrzałej duchowości głównym zadaniem Uniwersytetu Katolickiego. „Europa Christi”, nr 33 (dodatek Fundacji „Myśląc Ojczyzna", 25 października 2020), s. IV.

KozIELECKI, J. (1977). O godności czlowieka. Warszawa: Czytelnik 1977.

LeKKa-Kowalik, A. (2016). Godność podmiotów edukacji. W: K. ChaŁas, A. MaJ (red.), Encyklopedia aksjologii pedagogicznej (s. 384). Radom: Polskie Wydawnictwo Encyklopedyczne Polwen.

ŁABOCKi, M. (2002). Wychowanie moralne w zarysie. Kraków: Oficyna Wydawnicza „Impuls”.

MARIAŃSKI, J. (2016). Godność ludzka jako wartość spoleczno-moralna: mit czy rzeczywistość. Studium interdyscyplinarne. Torun: Wydawnictwo Adam Marszałek.

MARIAŃSKI, J. (2017). Godność ludzka - wartość ocalona. Studium socjopedagogiczne. Płock: Płocki Instytut Wydawniczy.

MAZUReK, F. J. (2001). Godność osoby ludzkiej podstawa praw czlowieka. Lublin: Redakcja Wydawnictw KUL.

NowaK, M. (2016). Mądrość. W: K. ChaŁas, A. Maj (red.), Encyklopedia aksjologii pedagogicznej (s. 572). Radom: Polskie Wydawnictwo Encyklopedyczne Polwen.

Podrez, E. (1993). Godność człowieka. W: W. PIwOWARSKI (red.), Słownik katolickiej nauki społecznej (s. 54-55). Warszawa: Instytut Wydawniczy PAX.

StĘPIEŃ, K. (2016). Godność osobowa. W: K. Chałas, A Maj (red.), Encyklopedia aksjologii pedagogicznej (s. 377-378). Radom: Polskie Wydawnictwo Encyklopedyczne Polwen.

SzosteK, A. (1989). Wokół godności, prawdy, miłości. Lublin: Redakcja Wydawnictw KUL.

WoJTYŁA, K. (1994). Osoba i czyn oraz inne studia antropologiczne. Lublin: Towarzystwo Naukowe KUL. 


\title{
GODNOŚĆ CZŁOWIEKA ŹRÓDŁEM CELÓW WYCHOWANIA I ZADAŃ SZKOŁY
}

\begin{abstract}
STRESZCZENIE
Godność osobowa jest wartością daną. Określa wartość człowieka jako osoby. Godność osobowościowa stanowi zadanie dla człowieka. Jest wartością zadaną, utracaną. U jej podstaw znajdują się działania moralnie wartościowe. Godność osobowa i osobowościowa są zintegrowane z rozumnością - mądrością, wolnością, odpowiedzialnością, ważnymi przymiotami osoby. Integracja ta generuje określane cele wychowania i zadania dla szkoły. Ich realizacja zapewnia integralny rozwój i integralne wychowanie.
\end{abstract}

Słowa kluczowe: godność osobowa; godność osobowościowa; cele wychowania; zadania szkoły.

\section{HUMAN DIGNITY AS A SOURCE OF EDUCATIONAL GOALS AND SCHOOL TASKS}

\section{SUMMARY}

Personal dignity is a given value. It determines the value of a human being as a person. Personal dignity is a task for people. It is an obtained value which can be lost. It is based on morally valuable activities. Personal and personality dignity are integrated with rationality-wisdom, freedom, responsibility - important qualities of a person. This integration generates specific educational goals and tasks for the school. Their implementation ensures integral development and integral education.

Keywords: personal dignity; personality dignity; goals of education; school tasks. 